\title{
КІЛЬКІСНА МОРФОЛОГІЧНА ОЦІНКА ОСОБЛИВОСТЕЙ РЕМОДЕЛЮВАННЯ СТРУКТУР М'ЯЗОВОї ОБОЛОНКИ ПОРОЖНЬОї КИШКИ ПРИ ПОРТАЛЬНІЙ ТА ЛЕГЕНЕВІЙ ГІПЕРТЕНЗІЯХ
}

\author{
๑О. Б. Слабий, Л. В. Татарчук, М. С. Гнатюк \\ ДВНЗ «Тернопільський державний медичний університет імені І. Я. Горбачевського МОЗ України»
}

РЕзЮМЕ. Видалення великих об'ємів паренхіми печінки і легень може супроводжуватися виникненням пострезекційної портальної і легеневої гіпертензій. Останні призводять до виражених змін гемодинаміки та морфологічної перебудови органів великого та малого кіл кровообігу. При цьому структура порожньої кишки та її м'язової оболонки зазнають змін, які у названих патологічних умовах досліджені недостатньо.

Мета - кількісними морфологічними методами вивчити особливості ремоделювання структур м'язової оболонки порожньої кишки при портальній та легеневій гіпертензіях.

Матеріал і методи. Дослідження проведені на 45 білих щурах-самцях, які були поділені на 3 групи. 1-а група нараховувала 15 інтактних тварин, 2-а - 15 щурів з пострезекційною портальною гіпертензією, 3-я - 15 тварин з легеневою артеріальною гіпертензією і декомпенсованим легеневим серцем. Артеріальну легеневу гіпертензію і декомпенсоване легеневе серце моделювали шляхом правосторонньої пульмонектомії. Пострезекційну портальну гіпертензію моделювали шляхом резекції 58,1 \% паренхіми печінки. Евтаназію дослідних тварин здійснювали кровопусканням в умовах тіопенталового наркозу через місяць від початку експерименту.

Вирізані шматочки порожньої кишки фіксували у 10 \% нейтральному розчині формаліну, після проведення через етилові спирти зростаючої концентрації їх поміщали у парафін і виготовляли гістологічні препарати. На гістологічних мікропрепаратах вимірювали товщину колового і поздовжнього шарів м'язової оболонки порожньої кишки, діаметри внутрішніх колових і зовнішніх поздовжніх міоцитів, їх ядер, ядерно-цитоплазматичні відношення у цих клітинах, відносні об'єми внутрішніх колових та зовнішніх поздовжніх міоцитів, відносні об'єми строми у коловому та поздовжньому шарах, стромально-міоцитарні відношення у них, відносні об'єми пошкоджених міоцитів у коловому та поздовжньому шарах. Кількісні показники обробляли статистично.

Результати. Видалення 58,1 \% паренхіми печінки призводило до розвитку пострезекційної портальної гіпертензії. Виражено зміненими при цьому виявилися морфометричні параметри структур колового та поздовжнього шарів м'язової оболонки порожньої кишки. Товщина колового шару м'язової оболонки через місяць після резекції 58,1 \% паренхіми печінки статистично достовірно зменшилася на 4,1 \%, діаметр міоцитів - на 6,1\%, ядерно-цитоплазматичні відношення у них зросли на 50,0%, стромально-міоцитарні відношення - на 14,3 \%, відносний об'єм пошкоджених міоцитів - у 14,4 раза. Діаметр зовнішніх поздовжніх міоцитів у даних експериментальних умовах виявився зменшеним всього на 1,6 \%, діаметр ядер зріс на 4,6 \% (p<0,01), ядерно-цитоплазматичні відношення - на 15,2 \% (р<0,001), стромально-міоцитарні відношення - на 14,1 \%, відносний об'єм пошкоджених міоцитів - у 8,1 раза. Морфологічна перебудова структур колового та поздовжнього шарів м'язової оболонки порожньої кишки в умовах артеріальної легеневої гіпертензії була менш вираженою. При цьому ядерно-цитоплазматичні відношення у внутрішніх колових міоцитах зросли на 30,2 \%, а у зовнішніх поздовжніх - на 12,4 , а відносні об'єми їх пошкоджень - відповідно у 8 та 5,9 раза.

Висновки. Видалення великих об'ємів паренхіми печінки призводить до пострезекційної портальної гіпертензії, а правостороння пульмонектомія - до артеріальної легеневої гіпертензії, легеневого серця та його декомпенсації. Змодельовані патологічні стани призводять до вираженої морфологічної перебудови (ремоделювання) структур колового та поздовжнього шарів м'язової оболонки порожньої кишки, яка характеризується диспропорційними нерівномірними змінами морфометричних параметрів гладких міоцитів, їх ядер, порушеннями ядерноцитоплазматичних відношень у цих клітинах, атрофією, зростанням стромальних структур та відносних об'ємів пошкоджених міоцитів у м'язовій оболонці, що може ускладнюватися дисфункцією ушкодженого органа. Більш виражені морфологічні зміни виявлені у коловому шарі м'язової оболонки порожньої кишки та в умовах пострезекційної портальної гіпертензії.

КлючовІ СловА: портальна гіпертензія, легенева гіпертензія, порожня кишка, м'язова оболонка, морфометрія.

Вступ. Порожня кишка є важливим органом травної системи, яка до сьогоднішнього дня вивчається морфологами і клініцистами при різних фізіологічних та патологічних станах $[3,13]$. Відомо, що порушення гемодинаміки можуть призводити до структурних змін у оболонках даного органа, які в умовах портальної та легеневої гіпертензій досліджені недостатньо.
Мета - кількісними морфологічними методами вивчити особливості ремоделювання структур м'язової оболонки порожньої кишки при портальній та легеневій гіпертензіях.

Матеріал і методи дослідження. Дослідження проведені на 45 лабораторних статевозрілих білих щурах-самцях, які були поділені на 3 групи. 1-а група нараховувала 15 інтактних тварин, 2-а - 
Огляди літератури, оригінальні дослідження, погляд на проблему, ювілеї

15 щурів з пострезекційною портальною гіпертензією, 3-я - 15 дослідних тварин з легеневою артеріальною гіпертензією і декомпенсованим легеневим серцем. Артеріальну легеневу гіпертензію і декомпенсоване легеневе серце моделювали шляхом правосторонньої пульмонектомії [9]. Пострезекційну портальну гіпертензію моделювали шляхом резекції 58,1 \% паренхіми печінки [3]. Оперативні втручання проводили в умовах тіопенталового наркозу з дотриманням правил асептики і антисептики. Евтаназію дослідних тварин здійснювали кровопусканням в умовах тіопенталового наркозу через місяць від початку експерименту.

Вирізані шматочки порожньої кишки фіксували у 10 \% нейтральному розчині формаліну і після проведення через етилові спирти зростаючої концентрації поміщали у парафін. Мікротомні зрізи товщиною 5-7 мкм забарвлювали гематоксиліномеозином, за ван-Гізон, Маллорі, Вейгертом, толуїдиновим синім [10]. На гістологічних мікропрепаратах вимірювали товщину колового шару (ТКШ) м'язової оболонки порожньої кишки, діаметри внутрішніх колових міоцитів (ДМК), їх ядер (ДЯК), ядерно-цитоплазматичні відношення у цих клітина (ЯЦВК), відносний об'єм внутрішніх колових міоцитів (ВОМК), відносний об'єм строми (ВОСК) у коловому шарі, стромально-міоцитарні відношення у ньому (СМВК), відносний об'єм пошкоджених міоцитів у коловому шарі (ВОПМК), товщину поздовжнього шару (ТПШ), діаметр зовнішніх поздовжніх міоцитів (ДМП), їх ядер (ДяП), ядерно-цитоплазматичні відношення у цих клітинах (ЯЦВП), відносний об'єм зовнішніх поздовжніх міоцитів (ВОМП), відносний об'єм строми у поздовжньому шарі (ВОСП), стромально-міоцитарні відношення у ньому (СМВП), відносний об'єм пошкоджених зовнішніх поздовжніх міоцитів (ВОПМП) [1].

При виконанні дослідів та евтаназії експериментальних тварин дотримувалися «Загальних етичних принципів експериментів на тваринах", ухвалених Першим національним конгресом з біоетики (Київ, 2001), та «Європейської конвенції про захист хребетних тварин, що використовуються в дослідних та інших наукових цілях»[4]. Кількісні показники обробляли статистично. Обробка результатів виконана у відділі системних статистичних досліджень ДВНЗ "Тернопільський державний медичний університет імені І. Я. Горбачевського MO3 України" в програмному пакеті STATISTIKA («Statsoft Inc., США»). Різницю між порівнювальними величинами визначали за критеріями Стьюдента та Манна-Уітні $[1,5]$.

Результати й обговорення. Отримані в результаті проведеного дослідження дані наведено в таблиці 1. Внаслідок усестороннього аналізу показників, представлених у таблиці, встановлено, що товщина колового шару м'язової оболонки непошкодженої порожньої кишки з вираженою статистично достовірною різницею $(p<0,001)$ в 1,4 раза перевищувала аналогічний морфометричний параметр поздовжнього шару. Неоднаковими при цьому виявилися діаметри внутрішніх колових та зовнішніх поздовжніх міоцитів та їх ядер у досліджуваних шарах м'язової оболонки порожньої кишки. Більші вказані кількісні морфологічні по-

Таблиця 1. Морфометрична характеристика м'язової оболонки порожньої кишки експериментальних тварин $(\mathrm{M} \pm \mathrm{m})$

\begin{tabular}{|c|c|c|c|}
\hline \multirow{2}{*}{ Показник } & \multicolumn{3}{|c|}{ Група спостереження } \\
\hline & $1-a$ & $2-a$ & 3-я \\
\hline ТКШ, МКM & $56,65 \pm 0,45$ & $54,30 \pm 0,42 *$ & $54,80 \pm 0,45^{*}$ \\
\hline ДМК, МКМ & $9,05 \pm 0,06$ & $8,50 \pm 0,03 * * *$ & $8,60 \pm 0,03 * * *$ \\
\hline ДЯК, мкм & $2,80 \pm 0,02$ & $3,06 \pm 0,02 * * *$ & $3,04 \pm 0,02 * * *$ \\
\hline ЯЦВК & $0,096 \pm 0,102$ & $0,144 \pm 0,002 * * *$ & $0,125 \pm 0,002 * * *$ \\
\hline BOMK, \% & $88,7 \pm 1,2$ & $87,2 \pm 1,2$ & $87,8 \pm 1,5$ \\
\hline BOCK, \% & $11,30 \pm 0,09$ & $12,80 \pm 0,07 * * *$ & $12,2 \pm 0,09 * * *$ \\
\hline CMBK & $0,126 \pm 0,001$ & $0,146 \pm 0,002 * * *$ & $0,138 \pm 0,002 * *$ \\
\hline ВОПМК, \% & $2,26 \pm 0,02$ & $22,6 \pm 0,36 * * *$ & $18,20 \pm 0,21 * * *$ \\
\hline ТПШ, мкм & $39,80 \pm 0,33$ & $33,80 \pm 0,36 * * *$ & $35,40 \pm 0,33 * * *$ \\
\hline ДМП, МКМ & $6,12 \pm 0,04$ & $6,02 \pm 0,03 * * *$ & $6,04 \pm 0,03$ \\
\hline ДЯП, мкм & $2,83 \pm 0,02$ & $2,96 \pm 0,02 * *$ & $2,93 \pm 0,02 * *$ \\
\hline ЯЦВП & $0,210 \pm 0,002$ & $0,242 \pm 0,003^{* * *}$ & $0,236 \pm 0,003^{* * *}$ \\
\hline ВОМП, \% & $88,6 \pm 1,2$ & $87,4 \pm 1,2$ & $88,0 \pm 1,5$ \\
\hline ВОСП, \% & $11,40 \pm 0,12$ & $12,60 \pm 0,09$ & $12,0 \pm 0,08 * *$ \\
\hline СМВП & $0,128 \pm 0,001$ & $0,144 \pm 0,002 * * *$ & $0,136 \pm 0,002^{* * *}$ \\
\hline ВОПМП, \% & $2,14 \pm 0,02$ & $17,30 \pm 0,12 * * *$ & $12,60 \pm 0,12 * * *$ \\
\hline
\end{tabular}

Примітки. * $-p<0,05 ; * *-p<0,01 ; * * *-p<0,001$, порівняно з 1-ю групою. 
Огляди літератури, оригінальні дослідження, погляд на проблему, ювілеї

казники колового шару м'язової оболонки, порівняно з поздовжнім, свідчать, що попередня структура інтенсивніше функціонує та виконує більшу роботу і $\epsilon$ більш потужною. Ядерно-цитоплазматичні відношення у внутрішніх колових міоцитах, стромально-міоцитарні відношення, відносні об' $\epsilon$ ми пошкоджених гладких міоцитів у досліджуваних шарах м'язової оболонки неушкодженої порожньої кишки підтверджували наведене вище.

У дослідних тварин через місяць після резекції 58,1 \% паренхіми печінки при розтині очеревинної порожнини спостерігалося розширення ворітної печінкової вени, повнокров'я і розширення брижових вен та видимого венозного русла тонкої та товстої кишок, асцит, спленомегалія. Слизова оболонка порожньої кишки повнокровна, набрякла, з поодинокими осередками точкових крововиливів. Описане вище свідчило про наявність пострезекційної портальної гіпертензії $[2,11]$. Правостороння пульмонектомія призводила до артеріальної легеневої гіпертензії, легеневого серця та його декомпенсації, яка характеризувалася малорухомістю тварин, втратою апетиту, задишкою, ціанозом видимих слизових оболонок, гідротораксом, гідроперикардом, асцитом та периферійними набряками [9].

Виявлено, що через місяць після резекції $58,1 \%$ паренхіми печінки товщина колового шару зменшилася на $4,1 \%(p<0,05)$, а в умовах декомпенсованого легеневого серця - на 3,3\%. Діаметри внутрішніх колових міоцитів у 2-й групі спостереження при цьому зменшилися на $6,1 \%$ $(p<0,001)$, у 3-й групі - на 5,0\% ( $<<0,001)$. Діаметри ядер вказаних міоцитів відповідно збільшилися на 9,3\% та 8,6 \% ( $<<0,001)$, а ядерно-цитоплазматичні відношення у досліджуваних клітинах - на $50,0 \%(p<0,001)$ та 30,2\% ( $<<0,001)$. Наведені зміни останніх морфометричних параметрів свідчили про виражене порушення структурного клітинного гомеостазу [8].

Відносні об'єми внутрішніх колових міоцитів $(p<0,05)$ у даних умовах експерименту суттєво не змінювалися, а відносний об'єм строми у 2-й групі спостережень зріс на 13,3 \% ( $<<0,001)$, у 3-й - на $8,0 \%(p<0,001)$. Відносний о6'єм пошкоджених внутрішніх колових міоцитів при портальній гіпертензії збільшився у 10,4 рази, а при легеневій гіпертензії - у 5,3 рази ( $<<0,001)$. Стромально-міоцитарні відношення при цьому відповідно зросли на $15,9 \%$ та на $9,5 \%(p<0,001)$.

У поздовжньому шарі м'язової оболонки порожньої кишки при пострезекційній портальній гіпертензії і при артеріальній легеневій гіпертензії морфологічна перебудова досліджуваних структур була аналогічна описаній. Ступінь вираження цих структурних змін був меншим, порів- няно $з$ наведеним вище. Так, діаметр зовнішніх поздовжніх міоцитів порожньої кишки при пострезекційній портальній гіпертензії зменшився на $1,6 \%$, а при декомпенсованому легеневому серці - на 1,3\%. Діаметри ядер вказаних гладких міоцитів відповідно збільшилися на 4,6 та 3,5 \% $(p<0,01)$, ядерно-цитоплазматичні відношення на 15,2 та $12,4 \%(p<0,001)$. Збільшеними в обох групах спостережень виявилися відносні об'єми строми та стромально-міоцитарні відношення. Так, при пострезекційній портальній гіпертензії відносний об' єм строми у поздовжньому шарі порожньої кишки зріс на 10,5 \% (p<0,01), при артеріальній легеневій гіпертензії - на 5,3\% $(p<0,01)$, а стромально-міоцитарні відношення, - відповідно на $12,5 \%(p>0,001)$ та 6,2\% ( $<<0,001)$. Відносний об'єм пошкоджених зовнішніх поздовжніх міоцитів у 2-й групі спостережень виявився статистично достовірно збільшеним $(p<0,001)$ у 8,08 раза, а при легеневій гіпертензії та декомпенсації легеневого серця - у 5,9 раза.

Морфологічні виміри структур м'язової оболонки порожньої кишки свідчать, що в умовах пострезекційної портальної гіпертензії та легеневої гіпертензії з декомпенсацією легеневого серця у досліджуваних структурах виникають атрофічні процеси (зменшення розмірів клітин, заміна пошкоджених клітин сполучною тканиною), що обумовлено гіпоксією, загальними процесами та імунними реакціями, що мають місце при змодельованій патології $[7,12]$.

Варто зазначити, що виявлені структурні зміни у м'язовій оболонці можуть призводити до порушення моторики та дисфункції кишки.

На основі отриманих даних проведеного дослідження та даних літератури можна стверджувати, що пострезекційні портальна та легенева гіпертензії призводять до вираженої структурної перебудови (ремоделювання) колового іпоздовжнього шарів м'язової оболонки порожньої кишки. При цьому виявлено, що пострезекційна портальна гіпертензія призводить до більш вираженої морфологічної перебудови структур м'язової оболонки порожньої кишки порівняно з пострезекційною легеневою гіпертензією. Це пояснюється більш вираженими змінами у венозному руслі досліджуваного порожнистого органа, що пов'язано з значним порушенням венозного дренажу з органів басейну ворітної печінкової вени $[2,14]$.

Світлооптично в оболонках стінки порожньої кишки спостерігалися виражені судинні розлади, набряки строми, осередки дистрофічно, некробіотично, апоптично змінених епітеліоцитів, гладких міоцитів, вогнищеві інфільтрати та розростання сполучної тканини. Відмічався також набряк ендотеліоцитів, їх дистрофія, некробіоз, проліфера- 
Огляди літератури, оригінальні дослідження, погляд на проблему, ювілеї

ція та осередки десквамації. Останнє свідчило про наявність гіпоксії. Виражене пошкодження більшості ендотеліоцитів може призводити до ендотеліальної дисфункції та посилювати ушкодження клітин та тканин [6]. Варто також зазначити, що виявлені патогістологічні ушкодження стінки порожньої кишки в умовах пострезекційної портальної гіпертензії корелювали з такими морфометричними параметрами, як ядерно-цитоплазматичні відношення у гладких міоцитах, стромально-міоцитарні відношення у м'язовій оболонці органа, відносний об'єм ушкоджених міоцитів. Відомо, що наявне венозне повнокров'я призводить до тканинної гіпоксії, яка сприяє депривації компенсаторних механізмів адаптації та зниженню резистентності клітинних структур до пошкоджувальної дії негативних чинників метаболізму [7, 12]. Атрофічні процеси (зменшення розмірів структур), заміна некротично змінених клітин сполучною тканиною, розростання строми у м'язовій оболонці досліджуваного органа в умовах пострезекційної портальної та легеневої гіпертензій, що обумовлено гіпоксією, запальними процесами та імунними реакціями [7,12], можуть призводити до порушення моторики та дисфункції кишки $[3,14]$.

На основі отриманих результатів проведеного дослідження та даних літератури можна стверджувати, що видалення великих об'ємів паренхіми печінки призводить до пострезекційної портальної гіпертензії, а правостороння пульмонектомія - до артеріальної легеневої гіпертензії, легеневого серця та його декомпенсації і виражених змін гемодинаміки, які ускладнюються вираженою структурною перебудовою (ремоделюванням) колового і поздовжнього шарів м'язової оболонки порожньої кишки, що характери- зується нерівномірними диспропорційними змінами просторових характеристик структур органа, порушенням відношень між ними, судинними розладами, набряком, дистрофічними, некробіотичними змінами епітеліоцитів, міоцитів, ендотеліоцитів, стромальних елементів, атрофічними, інфільтративними та склеротичними процесами. Домінують структурні зміни у коловому шарі м'язової оболонки порожньої кишки та в умовах пострезекційної портальної гіпертензії.

Висновки. Видалення великих об'ємів паренхіми печінки призводить до пострезекційної портальної гіпертензії, а правостороння пульмонектомія - до артеріальної легеневої гіпертензії, легеневого серця та його декомпенсації. Змодельовані патологічні стани призводять до вираженої морфологічної перебудови (ремоделювання) структур колового та поздовжнього шарів м'язової оболонки порожньої кишки, яка характеризується диспропорційними, нерівномірними змінами морфометричних параметрів гладких міоцитів, їх ядер, порушеннями ядерно-цитоплазматичних відношень у цих клітинах, атрофією, зростанням стромальних структур та відносних об'ємів пошкоджених міоцитів у м'язовій оболонці, що може ускладнюватися дисфункцією ушкодженого органа. Більш виражені морфологічні зміни виявлені у коловому шарі м'язової оболонки порожньої кишки та в умовах пострезекційної портальної гіпертензії.

Перспективи подальших досліджень. Всебічне адекватне вивчення закономірностей ремоделювання структур м'язової оболонки порожньої кишки в умовах пострезекційної портальної та легеневої гіпертензій дозволить суттєво розширити діагностику, корекцію та профілактику досліджуваних патологій.

\section{ЛІТЕРАТУРА}

1. Автандилов Г. Г. Основы количественной патологической анатомии / Г. Г. Автандилов. - М. : Медицина, 2002. - 240 c.

2. Вишневський В. А. Сегментарные резекции, отдаленные результаты при злокачественных опухолях печени / В. А. Вишневский, М. Г. Ефанов, И. В. Казаков // Укр. журнал хірургії. - 2012. - № 1 (16). - С. 5-15.

3. Гнатюк М. С. Морфометрична оцінка особливостей ремоделювання структур дванадцятипалої кишки при резекції різних об'ємів печінки / М. С. Гнатюк, Л. В. Татарчук, О. Б. Ясіновський // Науковий вісник Ужгородського університету. Серія «Медицина». 2016. - № 1 (53). - С. 92-95.

4. Загальні етичні принципи експериментів на тваринах // Ендокринологія. - 2003. - Т. 8, № 1. - С. 142-145.

5. Лапач С. Н. Статистические методы в медикобиологических исследованиях Excell / С. Н. Лапач, А. В. Губенко, П. Н. Бабич. - К. : Морион, 2001. - 410 с.

6. Макаров М. А. Роль дисфункции эндотелия и ригидности артерий в патогенезе хронической обструктивной болезни легких / М. А. Макаров, С. Н. Авдеев, А. Г. Чучалин // Терапевтический архив. - 2012. - № 3. - С. 74-80.

7. Мосийчук Л. Н. Хронический гастрит / Л. Н. Мосийчук, М. Ю. Зак // Новости медицины и фармации. 2010. - № 21 (349). - С. 12-15.

8. Саркисов Д. С. Структурные основы адаптации и компенсации нарушенных функций / Д. С. Саркисов. М. : Медицина, 1998. - 230 с.

9. Слабий О. Б. Особливості ремоделювання камер легеневого серця в залежності від типів централь- 
Огляди літератури, оригінальні дослідження, погляд на проблему, ювілеї

ної гемодинаміки / О. Б. Слабий // Світ медицини та біології. - 2016. - № 4 (58). - С. 124-126.

10. Сорочинников А. Г. Гистологическая и микроскопическая техника / А. Г. Сорочинников, А. Е. Доросевич. - М. : Медицина, 2007. - 448 с.

11. Федоров В. Д. Основные осложнения обширных резекций печени и пути их предупреждения / В. Д. Федоров, В. А. Вишневский, Н. А. Назаренко [и др.] // Бюлл. сибирской медицины. - 2007. - № 4. C. $16-24$.

12. Хухліна О. С. Бронхіальна астма та хронічний холецистит: особливості клітинного перебігу, меха- нізми взаємообтяження, шляхи патогенної корекції / О. С. Хухліна, Т. В. Дудка, Г. І. Шумко. - Чернівці : БДМУ, 2018. - 194 c.

13. Шульгай А. Г. Особливості ремоделювання судин гемомікроциркуляторного русла клубової кишки при резекціях різних об'ємів печінки / А. Г. Шульгай, л. В. Татарчук, М. С. Гнатюк // Вісник наукових досліджень. - 2017. - № 4. С. 148-149.

14. Nanashima A. A modified grading system for posthepatectomy metastatic liver cancer originating form colorectal carcinoma / A. Nanashima, Y. Sumida, T. Abo // J. Surg. Oncol. - 2008. - No. 98. - P. 363-370.

\section{REFERENCES}

1. Avtandilov, G.G. (2002). Osnovy kolichestvennoy patologicheskoy anatomii [Basis of quantitative pathological anatomy]. Moscow: Meditsina [in Russian].

2. Vishnevskiy, V.A., Yefanov, M.G., \& Kazakov, I.V. (2012). Segmentarnyye rezektsyi, otdalennyye rezultaty pri zlokachestvennykh opukholyakh pecheni [Segmentar resections, long-term results in malignant liver tumors]. Ukr. Zhurnal Khirurgii - Ukrainian Journal of Surgery, 1 (16), 5-15 [in Russian].

3. Hnatiuk, M.S., Tatarchuk, L.V. \& Yasinovskyi, O.B. (2016). Morfometrychna ostinka osoblyvostei remodeliuvannia struktur dvanadtsiatypaloi kyshky pry resektsii riznykh obiemiv pechinky [Morphometric evaluation of the features of remodeling of duodenal structures during resection of different volumes of the liver]. Naukovyi visnyk Uzhhorodskoho universytetu. Seriia "Medytsyna" - Scientific Journal of Uzhhorod University. Series "Medicine", 1 (49), 3-5 [in Ukrainian].

4. (2003). Zahalni etychni pryntsypy eksperymentiv na tvarynakh [General ethical principles of experiments on animals]. Endokrynolohiia - Endocrinology, 8, 1, 142-145 [in Ukrainian].

5. Lapach, S.N., Gubenko, A.V., \& Babich, P.N. (2001). Statisticheskiye metody $v$ mediko-biologicheskikh issledovaniyakh Excell [Statistical methods in medicobiological investigations Excell]. Kyiv: Morion [in Ukrainian].

6. Makarov, M.A., Avdyeyev, S.G., \& Chuchalin, A.G. (2012). Rol disfunktsyi endoteliya i regidnosti arteriy $v$ patogeneze khronicheskoy obstruktivnoy bolezni legkikh [Role disfunction endothelial cell in medical and biological investigation]. Terapevtichieskiy arkhiv - Theraputical Archive, 3, 74-80 [in Russian].

7. Mosiychuk, L.N., \& Zak, M.Yu. (2010). Khronicheskiy gastrit [Chronic gastritis]. Novosti meditsyny $i$ farmatsii News of Medicine and Pharmacy, 21 (349), 12-15 [in Russian].

8. Sarkisov, D.S. (1998). Strukturnyye osnovy adaptatsyi i kompensatsyi narushennykh funktsyy [Structural basis

adaptation and compensation damage function]. Moscow: Meditsina [in Russian].

9. Slabyi, O.B. (2016). Osoblyvosti remodeliuvania kamer lehenevoho sertsia vzalezhnostivid typiv tsentralnoi hemodynamiky [The features of remodeling chambers cor pulmonale at depending of central hemodynamical types]. Svit medytsyny i biolohii - World of Medicine and Biology, 4 (58), 124-126 [in Ukrainian].

10. Sorochinnikov, A.G., \& Dorosevich, A.Ye. (2007). Gistologicheskaya i mikroskopicheskaya tekhnika [Histological and microscopic equipment]. Moscow: Meditsyna [in Russian].

11. Fedorov, V.D., Vishnevskiy, V.A., \& Nazarienko, N.A. (2007). Osnovnyi oslozhnieniya obshyrnykh rezekcyi pecheni i puti ikh preduprezhdeniya [The main complications of extensive liver resections and ways to prevent them]. Byull. Sibirskoy meditsyny - Bulletin of Siberian Medicine, 4, 16-24 [in Russian].

12. Khukhlina, O.S., Dudka, T.V., \& Shumko, H.I. (2018). Bronkhialna astma ta khronichnyi kholetsystyt: osoblyvosti klitynnoho perebihu, mekhanizmy vzaiemoobtiazhennia, shliakhy patohennoi korektsii [Bronchial asthma and chronic cholecystitis: features of the cellular flow, mechanisms of mutual burden, pathogenic correction]. Chernivtsi: BDMU [in Ukrainian].

13. Shulhai, A.H., Tatarchuk, L.V., \& Hnatiuk, M.S. (2017). Osoblyvosti remodeliuvania sudyn hemomikrotsyrkuliatornoho rusla klubovoi kyshky pry resektsii riznykh obiemiv pechinky [Remodeling peculiarities of ileum hemomicrocirculatory bed vessels at resection of different liver size]. Visnyk naukovykh doslidzhen - Bulletin of Scientific Researches, 4, 145-149 [in Ukrainian].

14. Nanashima, A., Sumida, Y., \& Abo, T. (2008). A modified grading system for post-hepatectomy metastatic liver cancer originating form colorectal carcinoma. J. Surg. Oncol., 98, 363-370. 


\title{
Огляди літератури, оригінальні дослідження, погляд на проблему, ювілеї
}

\section{КОЛИЧЕСТВЕННАЯ МОРФОЛОГИЧЕСКАЯ ОЦЕНКА ОСОБЕННОСТЕЙ РЕМОДЕЛИРОВАННЯ СТРУКТУР МЫШЕЧНОЙ ОБОЛОЧКИ ТОЩЕЙ КИШКИ ПРИ ПОРТАЛЬНОЙ И ЛЕГОЧНОЙ ГИПЕРТЕНЗИЯХ}

\author{
๑О. Б. Слабый, Л. В. Татарчук, М. С. Гнатюк
}

\author{
ДВНЗ «Тернопольский государственный медицинский университет имени И. Я. Горбачевского \\ МОЗ Украины»
}

РЕЗЮМЕ. Удаление больших объемов паренхимы печени и легких может сопровождатся возникновением пострезекционной портальной и легочной гипертензий, которые приводят к выраженным изменениям гемодинамики и морфологической перестройке органов большого и малого кругов кровообращения. Изменяется при этом структура тощей кишки и ее мышечной оболочки, которые в названных патологических условиях исследованы недостаточно.

Цель - количественными морфологическими методами изучить особенности ремоделирования структур мышечной оболочки тощей кишки при портальной и легочной гипертензиях.

Материал и методы. Исследования проведены на 45 белых крысах-самцах, которые были поделены на 3 группы. 1-я группа насчитывала 15 интактных животных, 2-я - 15 крыс с пострезекционной портальной гипертензией, 3-я - 15 животных с легочной артериальной гипертензией и декомпенсированным легочным сердцем. Артериальную легочную гипертензию и декомпенсированное легочное сердце моделировали путем правостороронней пульмонэктомии. Пострезекционную портальную гипертензию моделировали путем резекции 58,1 \% паренхмы печени. Эвтаназию животных осуществляли кровопусканием в условиях тиопенталового наркоза через месяц от начала эксперимента.

Вырезанные кусочки тощей кишки фиксировали в 10 \% нейтральном растворе формалина, котрые после проведения через этиловые спирты возрастающей концентрации помещали в парафин и изготовляли гистологические препараты. На гистологических микропрепаратах измеряли толщины кругового и продольного слоев мышечной оболочки тощей кишки, диаметры внутренних круговых и наружных продольных миоцитов, их ядер, ядерно-цитоплазматические отношения в этих клетках, относительные объемы внутренних круговых и наружных продольных миоцитов, относительные объемы стромы в круговом и продольном слоях, стромально-миоцитарные отношения у них, относительные объемы поврежденных миоцитов в круговом и продольном слоях. Количественные показатели обрабатывали статистически.

Результаты. Удаление 58,1 \% паренхимы печени приводило к развитию пострезекционной портальной гипертензии. Выраженно измененными при этом оказались морфометрические параметры структур кругового и продольного слоев мышечной оболочки тощей кишки. Толщина кругового слоя мышечной оболочки тощей кишки при этом уменьшилась на 4,1\%, диаметра миоцитов - на 6,1 \%, ядерно-цитоплазматические отношения у них выросли на 50,0 \%, стромально-миоцитарные отношения - на 14,3%, относительный объем поврежденных миоцитов - в 14,4 раза. Диаметр наружных продольных миоцитов в данных экспериментальных условиях оказался уменьшенным всего на 1,6 \%, диаметр ядер вырос на 4,6 \% ( $<<0,01)$, ядерно-цитоплазматические отношения - на $15,2 \%$ ( $<<0,001)$, стромально-миоцитарные отношения - на 14,1 \%, относительный объем поврежденных миоцитов - в 8,1 раза. Толщины кругового и продольного слоев мышечной оболочки тонкой кишки в условиях артериальной легочной гипертензии были менее выраженными. При этом ядерно-цитоплазматические отношения во внутренних круговых миоцитах выросли на 30,2 \%, а в наружных продольных - на 12,4 \%, а относительные объемы их повреждений - соответственно в 8 и 5,9 раза.

Выводы. Удаление больших объемов паренхимы печени приводит к пострезекционной портальной гипертензии, а правосторонняя пульмонэктомия - к артериальной легочной гипертензии, легочному сердцу и его декомпенсации. Смоделированные патологические состояния сопровождаются выраженной морфологической перестройкой (ремоделированием) структур кругового и продольного слоев мышечной оболочки тощей кишки, которая характеризуется неравномерными изменениями морфометрических параметров гладких миоцитов, их ядер, нарушениями ядерно-цитоплазматических отношений в этих клетках, атрофией, ростом стромальных структур и относительных объемов поврежденных миоцитов в мышечной оболочке, что может осложняться дисфункцией поврежденного органа. Более выраженные морфологические изменения выявлены в круговом слое мышечной оболочки тощей кишки и в условиях пострезекционной портальной гипертензии.

КЛючЕВЫЕ словА: портальная гипертензия; легочная гипертензия; тощая кишка; мышечная оболочка; морфометрия. 


\title{
Огляди літератури, оригінальні дослідження, погляд на проблему, ювілеї \\ QUANTITATIVE MORPHOLOGICAL EVALUATION OF THE FEATURES REMODELING OF JEJUNUM MUSCULAR MEMBRANE STRUCTURE WHEN POSTRESECTION PORTAL AND PULMONARY HYPERTENSION
}

\author{
๑O. B. Slabyy, L. V. Tatarchuk, M. S. Hnatiuk

\section{Horbachevsky Ternopil State Medical University}

SUMMARY. Removal of large volumes of parenchyma of the liver and lungs may be accompanied by the onset of postresection portal and pulmonary hypertension. The latter leads to marked changes in hemodynamics and morphological rearrangement of the organs of large and small circulations. The structures of the jejunum and its muscular membrane, which under the mentioned pathological conditions is insufficiently studied.

The aim - to investigate the features of remodeling of the structures of the muscular membrane of the jejunum in portal and pulmonary hypertension, using quantitative morphological methods.

Material and Methods. The studies were conducted on 45 white male rats, which were divided into 3 groups. The group 1 consisted of 15 intact animals, 2 - 15 rats with postresection portal hypertension, and $3-15$ animals with pulmonary arterial hypertension and decompensated cor pulmonale. Arterial pulmonary hypertension and decompensated cor pulmonale were modeled by right pulmonectomy. Postresection portal hypertension was modeled by resection of $58.1 \%$ of liver parenchyma. Euthanasia of experimental animals was carried out by bloodletting under conditions of thiopental anesthesia 1 month after the beginning of the experiment. The cut pieces of the jejunum were fixed in a $10 \%$ neutral solution of formalin, which, after appropriate ethyl alcohol of increasing concentration, was poured in paraffin blocks and histological preparations were made. On histological micropreparations, the thickness of the circular and longitudinal layers of the muscular membrane of the jejunum, the diameters of internal circular and external longitudinal myocytes, their nuclei, nuclear-cytoplasmic relations in these cells, relative volumes of internal circular and outer longitudinal myocytes, relative volumes stroma in the circular and longitudinal layers, relative volumes of damaged myocytes. Quantitative indicators were processed statistically.

Results. Removal of $58.1 \%$ of liver parenchyma leads to the development of postresection portal hypertension. The morphometric parameters of the structures of the circular and longitudinal layers of the muscle of the jejunum were manifested mutated. The thickness of the circular muscle layer one month after resection of liver parenchyma $58.1 \%$ significantly decreased by $4.1 \%$, diameter of myocytes- $6.1 \%$, nuclear-cytoplasmic relation they increased by $50.0 \%$ ctromal-myocytic relation $-14.3 \%$, relative volume of damaged myocytes -14.4 times. The diameter of the outer longitudinal myocytes in these experimental conditions was reduced by only $1.6 \%$, the diameter of nuclei increased by $4.6 \%(p<0.01)$, nuclear-cytoplasmic relation - $15.2 \%(p<0.001)$, stromal-myocytic relation - by $14.1 \%$, relative volume of damaged myocytes - by 8.1 times. The morphological reorganization of the circular and longitudinal layers of the muscle of the jejunum under conditions of arterial pulmonary hypertension was less pronounced. At the same time nuclear-cytoplasmic relations in internal circular myocytes increased by $30.2 \%$, and in external longitudinal - by $12.4 \%$, and the relative volumes of their damage - respectively, in 8 and 5.9 times.

Conclusions. Removal of large volumes of liver parenchyma leads to postresection portal hypertension, and right pulmonectomy - to arterial pulmonary hypertension, cor pulmonare and its decompensation. Modified pathological conditions leads to pronounced morphological rearrangement (remodeling) of the structures of the circular and longitudinal layers of the muscular membrane of the jejunum, characterized by disproportional uneven changes in the morphometric parameters of smooth myocytes, their nuclei, nucleo-cytoplasmic relations in these cells, atrophy, growth of stromal structures and relative volumes of damaged myocytes in the muscular membrane, which may be complicated by the dysfunction of the damaged organ. More pronounced morphological changes were detected in the circular layer of the muscular membrane of the jejunum and at postresection portal hypertension.

KEY WORDS: portal hypertension; pulmonary hypertension; jejunum; muscular membrane; morphometry. 